Research Article

\title{
Effects of Arsenic Trioxide-Loaded PLGA Nanoparticles on Proliferation and Migration of Human Vascular Smooth Muscle Cells
}

\author{
Susu Zhao, ${ }^{1}$ Zeqian Yu, ${ }^{2}$ Yifen Zhang, ${ }^{1}$ and Mei Lin ${ }^{3}{ }^{3}$ \\ ${ }^{1}$ Department of Pathology, Affiliated Hospital of Nanjing University of Chinese Medicine, 210029 Nanjing, China \\ ${ }^{2}$ Department of Hepatic-Biliary-Pancreatic Center, Zhongda Hospital, Southeast University, 210029 Nanjing, China \\ ${ }^{3}$ Clinical Laboratory, Taizhou People's Hospital, Affiliated Hospital of Nanjing University of Chinese Medicine, \\ 225300 Taizhou, China
}

Correspondence should be addressed to Mei Lin; 1_mei@163.com

Received 14 February 2021; Revised 18 April 2021; Accepted 8 May 2021; Published 3 June 2021

Academic Editor: Luis Jesús Villarreal-Gómez

Copyright (c) 2021 Susu Zhao et al. This is an open access article distributed under the Creative Commons Attribution License, which permits unrestricted use, distribution, and reproduction in any medium, provided the original work is properly cited.

Backgroud. To evaluate improvement of arsenic trioxide-loaded PLGA nanoparticles $\left(\mathrm{As}_{2} \mathrm{O}_{3}\right.$-PLGA-NPs) to Human Vascular Smooth Muscle Cells (HUVSMCs) in vitro. Methods. $\mathrm{As}_{2} \mathrm{O}_{3}$-PLGA-NPs were synthesized and characterized by transmission electron microscopy (TEM), scanning electron microscope (SEM), and energy dispersive spectrometry (EDS), and the cumulative release rates of $\mathrm{As}_{2} \mathrm{O}_{3}$-PLGA-NPs were measured in vitro; HUVSMCs were treated with $\mathrm{As}_{2} \mathrm{O}_{3}$-PLGA-NPs in vitro. MTT assay and flow cytometry assay (FCM) were performed to examine the inhibitory effect of $\mathrm{As}_{2} \mathrm{O}_{3}$-PLGA-NPs on HUVSMCs and compared with $\mathrm{As}_{2} \mathrm{O}_{3}$ solution at various concentrations. Optical microscope was used to observe the morphological change of HUVSMCs treated with $\mathrm{As}_{2} \mathrm{O}_{3}$-PLGA-NPs. The expression of Bcl-2, Bax, and MMP-9 in HUVSMCs was detected by RT-PCR and Western blot (WB). Results. EDS confirmed that prepared nanoparticles contained elements of arsenic. The surface coating of the eluting stent of $\mathrm{As}_{2} \mathrm{O}_{3}-\mathrm{PLGA}-\mathrm{NPs}$ has the same characteristics with our self-prepared $\mathrm{As}_{2} \mathrm{O}_{3}-$ PLGA-NPs, and it also has a drug sustained-release character. Compared with the control group, cell proliferation and migration cell were significantly suppressed with concentration-dependent $(P<0.05$, respectively). Meanwhile, in concentrationdependent, $\mathrm{As}_{2} \mathrm{O}_{3}$-PLGA-NPs depressed mRNA and protein expression of Bcl-2 and MMP-9 and increased mRNA and protein expression of Bax. Conclusion. $\mathrm{As}_{2} \mathrm{O}_{3}$-PLGA-NPs had an inhibitory effect on HUVSMCs' proliferation and migration, and it may work via regulating Bax, Bcl-2, and MMP-9 expression in vitro.

\section{Introduction}

Although percutaneous coronary intervention (PCI) plays an important role in the treatment of coronary artery disease, there is still a risk of stent restenosis [1]. Vascular smooth muscle cells (VSMCs) are a key part in intimal thickening of in-stent restenosis (ISR) [2, 3]. Arsenic compounds are natural substances that can effectively inhibit acute promyelocytic leukemia (APL) [4]. Related studies have shown that arsenic trioxide $\left(\mathrm{As}_{2} \mathrm{O}_{3}\right)$ has a therapeutic effect on other types of malignant tumors [5-7]. $\mathrm{As}_{2} \mathrm{O}_{3}$ can effectively inhibit cell proliferation and has been widely used in clinical practice. The dosage forms of $\mathrm{As}_{2} \mathrm{O}_{3}$ were proposed $[8,9]$.
Drugs encapsulated in nanomaterials can effectively improve drug stability, release durability and biosafety, and reduce drug biodegradation. Polylactic-co-glycolic acid (PLGA) is a synthetic copolymer of poly (lactic acid) (PLA) and poly (glycolic acid) (PLGA). A large number of experimental studies have proved that PLGA is an important biomedical polymer material with good biodegradability and biocompatibility. It does not cause an obvious inflammatory reaction, immune reaction, and cytotoxic reaction [10]. PLGA has been approved by the US Food and Drug Administration (FDA) as a material for injection drugs, nanoparticles, implants, and other preparations and is widely used in the research of drug delivery system. Therefore, we choose PLGA 
as the drug carrier. In this study, we prepared arsenic trioxide- $\left(\mathrm{As}_{2} \mathrm{O}_{3}{ }^{-}\right)$loaded PLGA nanoparticles $\left(\mathrm{As}_{2} \mathrm{O}_{3}\right.$-PLGA$\mathrm{NPs}$ ), investigated their general properties and $\mathrm{As}_{2} \mathrm{O}_{3}$ bioactivity, and evaluated the effects of $\mathrm{As}_{2} \mathrm{O}_{3}$-PLGA-NPs on proliferation and migration of Human Vascular Smooth Muscle Cells (HUVSMCs). To clarify the molecular mechanism of HUVSMCs apoptosis induced by trioxide-loaded PLGA nanoparticles, the expression of $\mathrm{Bax}, \mathrm{Bcl}-2$, and MMP-9 was examined.

\section{Materials and Methods}

2.1. Materials. $\mathrm{As}_{2} \mathrm{O}_{3}, \mathrm{DEPC}$, Triblue, HRP-labeled goat antimouse IgG secondary antibody, and 5-diphenyl-2H-tetrazoliumbromide (MTT) were supplied by Sigma Corporation (USA). HUVSMCs, bought from Sciencell Corporation (USA), were maintained in Smooth muscle cell medium (SMCM, also provided by Sciencell Corporation). AMV reverse transcriptase, DNTP, Oligo (dT) 18, Taq DNA polymerase, RNasin, RNase free DNase I, and 100bp DNA Molecular Weight Marker were purchased from Takara Biotechnology Corporation (Japan). GENMED-Bradford Protein Concentration Quantitative Kit was purchased from Pharmaceutical Technology Corporation (Shanghai, China). Relative antibody was supplied by ZSGB-BIO Engineering Corporation (Beijing, China).

2.2. Preparation of the $\mathrm{As}_{2} \mathrm{O}_{3}-\mathrm{PLGA}-\mathrm{NPs}$ and their Characteristics. Referencing our previous research, we prepared $\mathrm{As}_{2} \mathrm{O}_{3}$-PLGA-NPs $[11,12]$. After $10 \mu \mathrm{l}$ suspension was aspirated, using transmission electron microscope (TEM), scanning electron microscopy (SEM), energy dispersive spectrometer (EDS), and computer color magic image analysis system to observe characteristics.

2.3. Determination of Drug Loading and Encapsulation Ratio of $\mathrm{As}_{2} \mathrm{O}_{3}$. Appropriate amount of $\mathrm{As}_{2} \mathrm{O}_{3}$-PLGA-NPs colloidal suspension was added at $4^{\circ} \mathrm{C}$. After centrifugation at 15000 $\mathrm{R} / \mathrm{min}$ for $30 \mathrm{~min}$, the precipitate was washed three times with deionized water, and the supernatant was mixed. The precipitate was frozen in a vacuum to obtain the lyophilized powder, and then, a certain amount of deionized water was used to fix the volume. The amount of $\mathrm{As}_{2} \mathrm{O}_{3}$ in the precipitate (W1) and the amount of free $\mathrm{As}_{2} \mathrm{O}_{3}$ in the combined supernatant (W2) were determined by hydride generation atomic fluorescence spectrometry, and the amount of $\mathrm{As}_{2} \mathrm{O}_{3}$ in $\mathrm{As}_{2} \mathrm{O}_{3}-\mathrm{PLGA}-\mathrm{NPs}=\mathrm{W} 1$, the total amount of $\mathrm{As}_{2} \mathrm{O}_{3}=\mathrm{W} 1+\mathrm{W} 2$. The drug loading and entrapment efficiency of the nanoparticles were calculated according to the following formula ( $\mathrm{W}_{\text {PLGA }}$ was the amount of PLGA added):

$$
\begin{aligned}
\text { Drug loading }(\%) & =\mathrm{W} 1 / \mathrm{W}_{\mathrm{PLGA}} \times 100 \% \\
\text { Encapsulation efficiency }(\%) & =\mathrm{W} 1 /(\mathrm{W} 1+\mathrm{W} 2) \times 100 \%
\end{aligned}
$$

2.4. In Vitro Release Test. $5 \mathrm{mg}$ of $\mathrm{As}_{2} \mathrm{O}_{3}$-PLGA-NPs accurately weighed and dispersed in a final volume of $5 \mathrm{~mL}$ normal saline and, then, sealed in a pretreated dialysis bag. The bag was immersed in a conical bottle containing $30 \mathrm{~mL}$ saline with constant rate stirring $(50 \mathrm{r} / \mathrm{min})$ at $37^{\circ} \mathrm{C} \pm 1^{\circ} \mathrm{C}$. The samples were taken at the same time point on the $1 \mathrm{st}, 2 \mathrm{nd}, 3 \mathrm{rd}$, 4 th, 5th, 6th, 7th, 8th, 9th, 10th, 11th, 12th, 13th, 14th, and 15 th day, respectively. At the same time, the same amount of $(1 \mathrm{~mL})$ release medium was added to determine the content of $\mathrm{As}_{2} \mathrm{O}_{3}$ in the release solution, and the curve of time and cumulative release concentration was drawn.

2.5. Cell Culture. HUVSMCs were maintained in SMCM and cultured at $37^{\circ} \mathrm{C}$ in a $5 \%(v / v) \mathrm{CO}_{2}$ atmosphere. HUVSMCs in the logarithmic growth stage were taken in the experiment.

2.6. MTT Assay. HUVSMCs were seeded in a 96-well plate with 5,000 cells per well and, after $24 \mathrm{~h}$ incubation, were treated for 1-5 d by different methods as follows: (1) a negative control group (SMCM), (2) $1 \mu \mathrm{mol} / \mathrm{L} \quad \mathrm{As}_{2} \mathrm{O}_{3}$, (3) $1 \mu \mathrm{mol} / \mathrm{L} \quad \mathrm{As}_{2} \mathrm{O}_{3}-\mathrm{PLGA}-\mathrm{NPs}$, (4) $3 \mu \mathrm{mol} / \mathrm{L} \quad \mathrm{As}_{2} \mathrm{O}_{3}$, (5) $3 \mu \mathrm{mol} / \mathrm{L} \mathrm{As} \mathrm{O}_{2} \mathrm{O}_{3}$-PLGA-NPs, (6) $6 \mu \mathrm{mol} / \mathrm{L} \mathrm{As} \mathrm{A}_{2} \mathrm{O}_{3}$, and (7) $6 \mu \mathrm{mol} / \mathrm{L} \mathrm{As}_{2} \mathrm{O}_{3}$-PLGA-NPs; then, $20 \mu \mathrm{l} \mathrm{MTT}(5 \mathrm{mg} / \mathrm{mL})$ was added and continued to incubate for $4 \mathrm{~h}\left(37^{\circ} \mathrm{C}, 5 \%\right.$ $\mathrm{CO}_{2}$ ). Finally, $150 \mu \mathrm{l}$ DMSO was added and shaking for $10 \mathrm{~min}$. The absorbance was measured at $492 \mathrm{~nm}$ using a spectrophotometer. The following formula was used to calculate the cell viability percentage (VP) [13]:

$\mathrm{VP}=\mathrm{OD}$ of experimental group/OD of control group $\times 100 \%$

2.7. Flow Cytometry Assay. Cells were treated $24 \mathrm{~h}$ by four different groups as follows: (1) a negative control group (SMCM), (2) $1 \mu \mathrm{mol} / \mathrm{L} \quad \mathrm{As}_{2} \mathrm{O}_{3}$-PLGA-NPs, (3) $3 \mu \mathrm{mol} / \mathrm{L}$ $\mathrm{As}_{2} \mathrm{O}_{3}$-PLGA-NPs, and (4) $6 \mu \mathrm{mol} / \mathrm{L} \quad \mathrm{As}_{2} \mathrm{O}_{3}$-PLGA-NPs; after $24 \mathrm{~h}$, cells were collected and washed in cold PBS (0.1 M, pH 7.2-7.4) three times, resuspended and fixed in $70 \%$ ethanol at $4^{\circ} \mathrm{C}$ for $10 \mathrm{~min}$ in the dark. According to the protocol of the kit for measuring cell apoptosis, the cell apoptosis rate of each group was detected by flow cytometry.

2.8. Inhibitory Effect of $\mathrm{As}_{2} \mathrm{O}_{3}-\mathrm{PLGA}-\mathrm{NPs}$ on HUVSMCs Migration Was Determined by Transwell Chamber Experiment. Logarithmic HUVSMCs were selected, and $\mathrm{As}_{2} \mathrm{O}_{3}$-PLGA-NPs with different concentrations (excluding serum) were added to the experimental groups, to reach the final concentrations of $1 \mu \mathrm{mol} / \mathrm{L}, 3 \mu \mathrm{mol} / \mathrm{L}$, and $6 \mu \mathrm{mol} / \mathrm{L}$, adding culture medium to the blank control group. $200 \mu \mathrm{l}$ cell suspension was inoculated on the Transwell insert (the pore size was $8 \mu \mathrm{m}$ ), and then, the upper chamber was put into the culture hole; the cells were cultured for 12 hours; the smooth muscle cells migrated to the subventricular surface of the filter membrane were photographed under a microscope and counted. The 5 cells under a high power field were taken from each sample.

2.9. Detection of Bcl-2, Bax, and MMP-9 Expressions by RT$q P C R$. NP was added to HUVSMCs to reach the final administration concentrations of $3 \mu \mathrm{mol} / \mathrm{L}$ and $6 \mu \mathrm{mol} / \mathrm{L}$; SMCM was added to the control group. After 72 hours of culture, the total RNA was extracted by Trizol. The primer sequences of Bax, Bcl-2, and MMP-9 in RT-qPCR reaction and 
TABLE 1: The relative sequence.

\begin{tabular}{lcc}
\hline Gene name & F: $\left(5^{\prime}-3^{\prime}\right)$ & $\mathrm{R}:\left(5^{\prime}-3^{\prime}\right)$ \\
\hline Bcl-2 & TGTGGCCTTCTTTGAGTTCG & TCACTTGTGGCTCAGATAGG 3 \\
Bax & GCGTCCACCAAGAAGCTGAG & ACCACCCTGGTCTTGGATCC \\
MMP-9 & GAGACCGGTGAGCTGGATAG & TACACGCGAGTGAAGGTGAG \\
GAPDH & AGCCTCAAGATCATCAGCAATG & TGTGGTCATGAGTCCTTCCACG \\
\hline
\end{tabular}

reference GAPDH gene were listed in Table 1, which was designed and synthesized by Sangon Biotech (Shanghai) Co., Ltd. The data detected and analyzed by IQ5TM Realtime PCR Detection System and expressed by $2^{-\Delta \Delta \mathrm{Ct}}$.

2.10. Detection of Bcl-2, Bax, and MMP-9 Expressions by Western-Blot (WB). NP was added to HUVSMCs to reach the final administration concentrations of $3 \mu \mathrm{mol} / \mathrm{L}$ and $6 \mu \mathrm{mol} / \mathrm{L}$; SMCM was added to the control group. After 72 hours of culture, the HUVSMCs of each group were lysed and the total proteins of each group were extracted. The actual concentration of total protein extracted from each group was determined; total protein for each sample $(50 \mu \mathrm{g})$ was developed by 10\% SDS-PAGE gel electrophoresis and Western blot, scanned by gel imaging system, and the images were saved and analyzed by Gel-pro32; the results were expressed by OD value.

2.11. Statistical Analysis. The data were shown as mean \pm SD, and the significance of difference with the control group was subject to the Poisson distribution and ANOVA variance analysis; $P<0.05$ means the difference is statistically significant, and the statistical process was completed by statistical software SAS8.1 and SPSS17.0.

\section{Results and Discussion}

3.1. General Characteristics of NP. The prepared NP is a milky white colloid. There is no delamination deposition at $4^{\circ} \mathrm{C}$ for $12 \mathrm{~h}$. NP has a slight delamination after 24 hours and can be suspended stably after ultrasonic processing for $1 \mathrm{~min}$.

3.2. Electron Microscopic Observation. After ultrasonic dispersion, the prepared NP was observed by transmission electron microscope (Figure 1(a)) and scanning electron microscope (Figure 1(b)); it was nearly circular and had a certain electron density, showing dispersed spheres. The average particle size of NP prepared in this experiment is calculated to be $90 \pm 31 \mathrm{~nm}$ by using the CMIAS98A image analysis system.

3.3. EDS Detection. Several visual fields under scanning electron microscope were selected, and the components of NP were analyzed by energy disperse spectroscopy (Figure 1(c)); it can be seen that it contains components of As, $\mathrm{C}$, and $\mathrm{O}$; the weight percentage content (wt\%) of As was $3.25 \%$ and the atomic percentage content (At\%) was $0.72 \%$. Therefore, it can be confirmed that NP has been successfully prepared.
3.4. Dynamic Determination Results of $\mathrm{As}_{2} \mathrm{O}_{3}$ Release from PLGA NPs. The in vitro dynamic release of NP was investigated with saline as medium; the cumulative release rate of the drug reached $72.37 \%$ on the 4 th day and $96.82 \%$ on the 15 th day and gradually entered the platform stage (Figure 2).

3.5. MTT Results. The growth rates of $\mathrm{As}_{2} \mathrm{O}_{3}$ and NP (NP) with different concentrations on HUVSMCs were listed in Table 2. It was found in the experiment that both $\mathrm{As}_{2} \mathrm{O}_{3}$ and NP could inhibit the growth of HUVSMCs and produce certain cytotoxicity and showed an obvious time and concentration-dependent relationship $(P<0.05)$. MTT results showed that after $6 \mu \mathrm{M} \mathrm{NP}$ treatment for 3 days, it had an inhibitory effect on the proliferation of HUVSMCs, while its toxicity was the least. The relative data was shown in Table 2.

3.6. Flow Cytometer Detection Results. The detection results of flow cytometer showed apoptosis rate of NP intervention group significantly increased $(P<0.05)$, and the apoptosis rate increased gradually with the increase of drug concentration. The data was shown in Figure 3.

3.7. Results of Transwell Cell Migration Assay. The results of Transwell showed a number of invasive cells in NP intervention group decreased significantly $(P<0.05$, Figure 4$)$, and NP inhibited migration of HUVSMCs in a concentration dependent manner.

3.8. Detection of Related mRNA Expression by RT-qPCR. Compared with the control group, Bcl-2 and MMP-9 genes in NP intervention group decreased significantly, while Bax gene significantly increased $(P<0.05$, Figure 5$)$, showing a significant concentration-effect relationship.

3.9. Detection of Related Protein Expression by WB. Compared with the control group, Bcl-2 and MMP-9 proteins in NP intervention group decreased significantly, while Bax protein significantly increased $(P<0.05$, Figure 6$)$, showing a significant concentration-effect relationship.

3.10. Discussion. In this experiment, referencing our previous research, emulsification evaporation technique was used to prepare NP, in which emulsion solvent was prepared by mechanical stirring or phacoemulsification of the two immiscible phases. The internal phase solvent was removed by evaporation, and the spherical material was precipitated and solidified into microspheres. The internal disperse phase solvent must have certain solubility and volatility in the external continuous phase. Under slow stirring condition, the internal disperse phase solvent diffuses to the external 


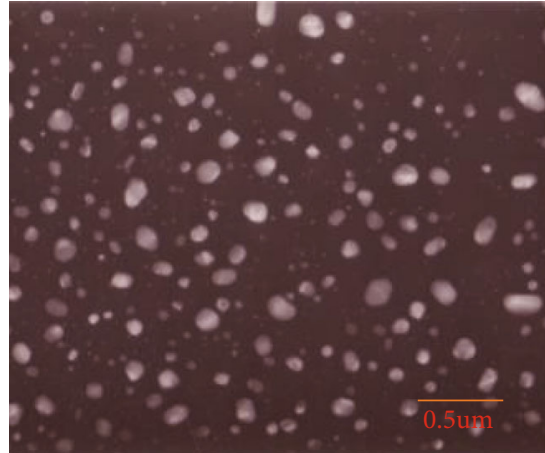

(a)

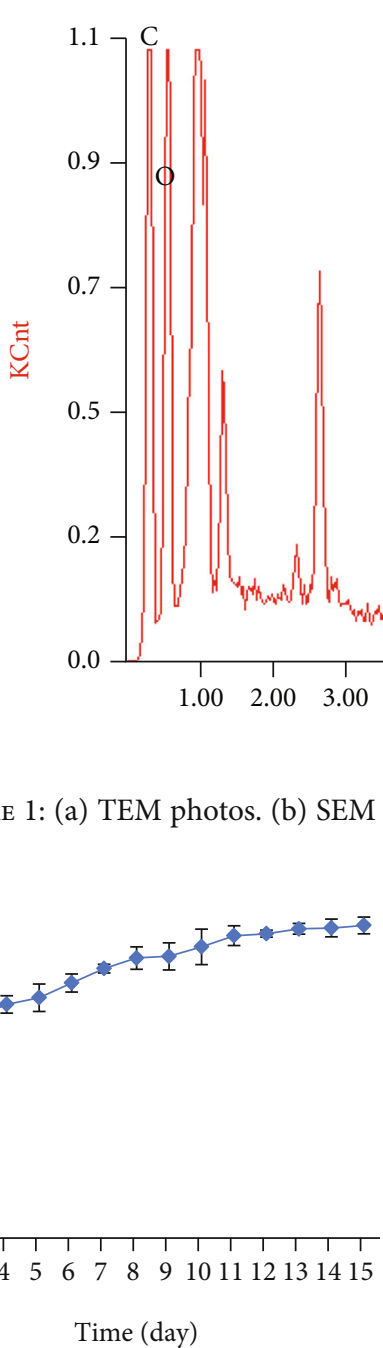

FIgURE 2: Cumulative release rate of $\mathrm{AS}_{2} \mathrm{O}_{3}$ from nano- $\mathrm{AS}_{2} \mathrm{O}_{3} /$ PLGA.

phase, transports to the liquid level, and volatilizes into the air. The extraction-volatilization-extraction process was repeated, so that the carrier material in the internal dispersion phase precipitated to form a capsule, and the drug was wrapped therein until the microspheres were completely cured. In this experiment, the organic phase was PLGA/dichloromethane solution with $\mathrm{As}_{2} \mathrm{O}_{3}$, and the aqueous phase was a PVA aqueous solution of a certain concentration; after the two phases were mixed, the emulsion was prepared by

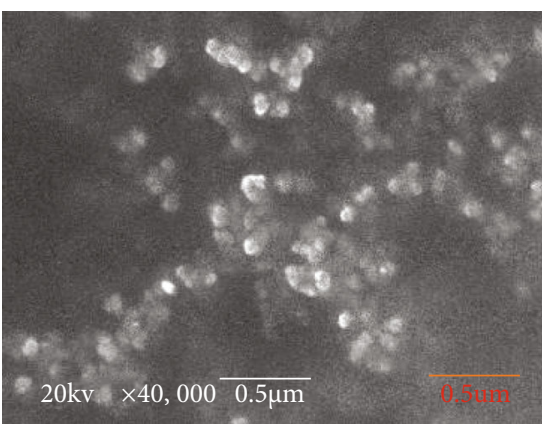

(b)

LSecs: 75

(c)

(c) Detection results of nano- $\mathrm{AS}_{2} \mathrm{O}_{3} /$ PLGA by EDS.

magnetic stirring; with the gradual removal of dichloromethane by evaporation, the spherical nanomaterials were precipitated and freeze-dried to form nanomicrospheres.

At present, it is recognized that the mechanism of ISR formation is a key part in excessive proliferation induced by injury and migration of VSMCs to inner membrane in addition to elastic retraction and thrombosis of vascular wall after vasodilation. Therefore, the search for drugs that inhibit the proliferation and migration of VSMC has become a hot topic in the study of ISR [14]. In this experiment, the effects of NP and $\mathrm{As}_{2} \mathrm{O}_{3}$ of different concentrations on HUVSMCs were studied. Under inverted microscope, after HUVSMCs was treated with $3 \mu \mathrm{mol} / \mathrm{L} \mathrm{As}_{2} \mathrm{O}_{3}$ for $24 \mathrm{~h}$, the cells began to round and wrinkle, and cell number decreased significantly. MTT assay results of NP and $\mathrm{As}_{2} \mathrm{O}_{3}$ of different concentrations for the HUVSMCs showed that NP was a sustained release system with good biocompatibility and also had an antiproliferation potential. $\mathrm{As}_{2} \mathrm{O}_{3}$ and NP had inhibitory effect on growth of HUVSMCs in a time-and concentrationdependent manner. MTT assay results showed effect of $\mathrm{As}_{2} \mathrm{O}_{3}$ on HUVSMCs entered the platform stage on the $3 \mathrm{rd}$ day, but the inhibitory effect of the $\mathrm{As}_{2} \mathrm{O}_{3}$ of same concentration on the cells before entering the platform stage was almost 
TABLE 2: The cell viability percentage of difference groups (\%) (mean $\pm s)$.

\begin{tabular}{|c|c|c|c|c|c|}
\hline Group & $1 d$ & $2 \mathrm{~d}$ & $3 d$ & $4 d$ & $5 \mathrm{~d}$ \\
\hline Control & 100 & 100 & 100 & 100 & 100 \\
\hline $1 \mu \mathrm{M} \mathrm{As}{ }_{2} \mathrm{O}_{3}$ & $97.13 \pm 0.64^{*}$ & $92.56 \pm 0.81^{*}$ & $88.76 \pm 2.07^{*}$ & $85.76 \pm 0.93^{*}$ & $82.58 \pm 5.34^{*}$ \\
\hline $1 \mu \mathrm{M}$ NP & $99.42 \pm 0.58^{*}$ & $96.24 \pm 1.39^{*}$ & $90.32 \pm 3.24^{*}$ & $84.23 \pm 3.27^{*}$ & $79.36 \pm 7.23^{*}$ \\
\hline $3 \mu \mathrm{M} \mathrm{As}{ }_{2} \mathrm{O}_{3}$ & $63.27 \pm 3.26^{*}$ & $56.73 \pm 1.59^{*}$ & $39.78 \pm 1.69^{*}$ & $36.92 \pm 0.85^{*}$ & $26.64 \pm 2.87^{*}$ \\
\hline $3 \mu \mathrm{M}$ NP & $70.51 \pm 1.74^{*}$ & $62.04 \pm 0.78^{*}$ & $45.27 \pm 0.81^{* \#}$ & $37.84 \pm 1.22^{*}$ & $21.39 \pm 1.57^{*}$ \\
\hline $6 \mu \mathrm{M} \mathrm{As} \mathrm{O}_{3}$ & $46.38 \pm 2.39^{*}$ & $30.28 \pm 4.25^{*}$ & $12.58 \pm 1.31^{*}$ & $7.23 \pm 1.56^{*}$ & $6.24 \pm 0.99^{*}$ \\
\hline $6 \mu \mathrm{M}$ NP & $50.23 \pm 6.81^{*}$ & $37.51 \pm 2.23^{*}$ & $22.69 \pm 2.43^{* \#}$ & $6.42 \pm 0.39^{*}$ & $5.13 \pm 0.48^{*}$ \\
\hline
\end{tabular}

${ }^{*} P<0.05$, compared with Control; ${ }^{\#} P<0.05$, compared with $\mathrm{As}_{2} \mathrm{O}_{3}$ group.

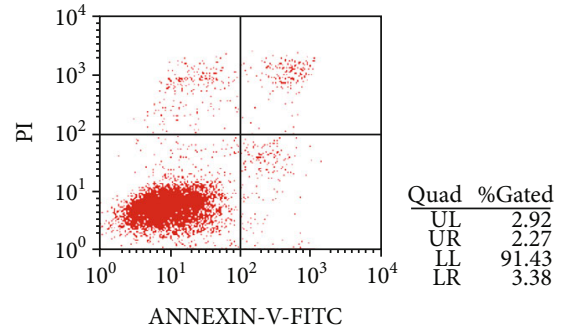

ANNEXIN-V-FITC

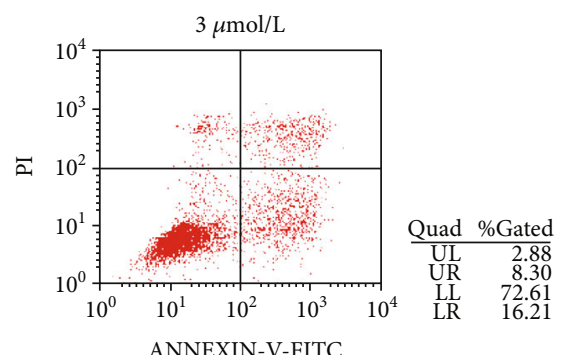

ANNEXIN-V-FITC
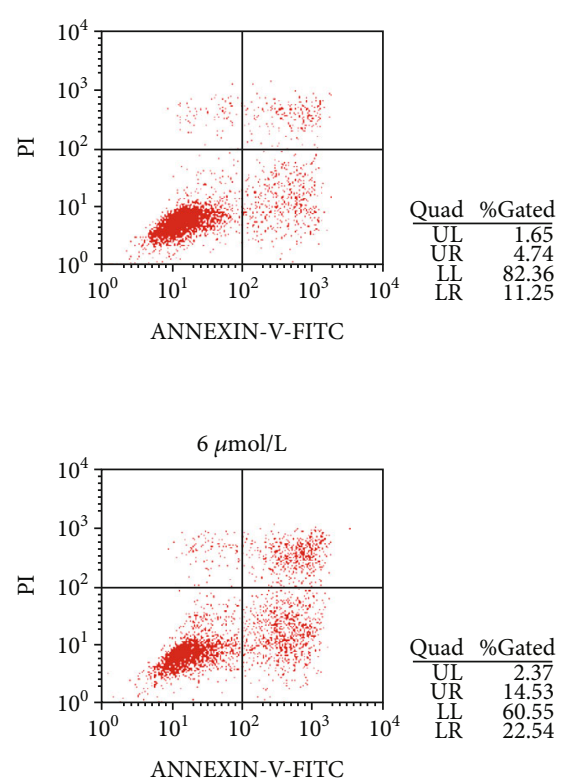

Figure 3: Flow cytometer detection results. ${ }^{*} P<0.05,{ }^{* *} P<0.01,{ }^{* * *} P<0.001$, compared with the control group; ${ }^{\#} P<0.05$, ${ }^{\# \#} P<0.01$, compared with $1 \mu \mathrm{mol} / \mathrm{L}$ group; ${ }^{8} P<0.05$, compared with $3 \mu \mathrm{mol} / \mathrm{L}$ group.

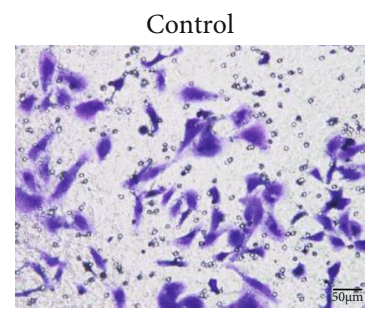

$3 \mu \mathrm{mol} / \mathrm{L}$

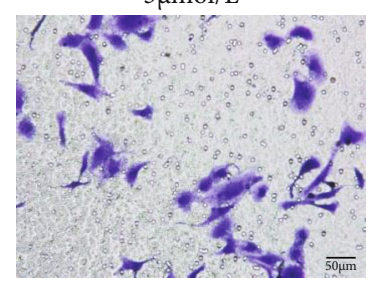

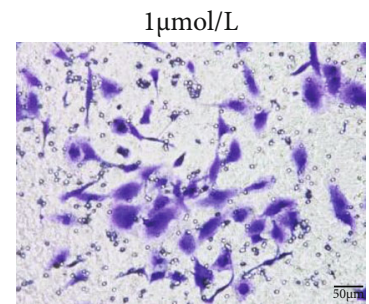

$6 \mu \mathrm{mol} / \mathrm{L}$

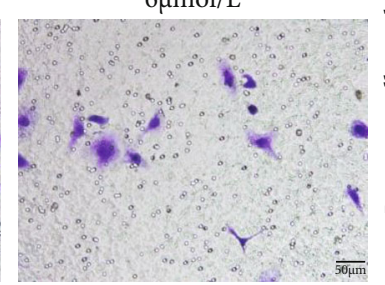

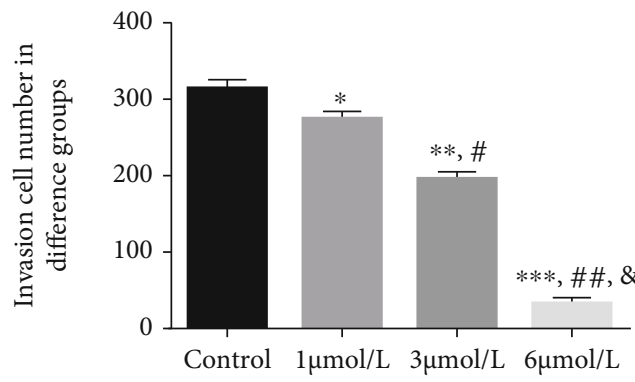

Figure 4: Results of Transwell cell migration assay. ${ }^{*} P<0.05,{ }^{* *} P<0.01,{ }^{* * *} P<0.001$, compared with the control group; ${ }^{\#} P<0.05$, ${ }^{\# \#} P<0.01$, compared with $1 \mu \mathrm{mol} / \mathrm{L}$ group; ${ }^{\circledR} P<0.05$, compared with $6 \mu \mathrm{mol} / \mathrm{L}$ group. 

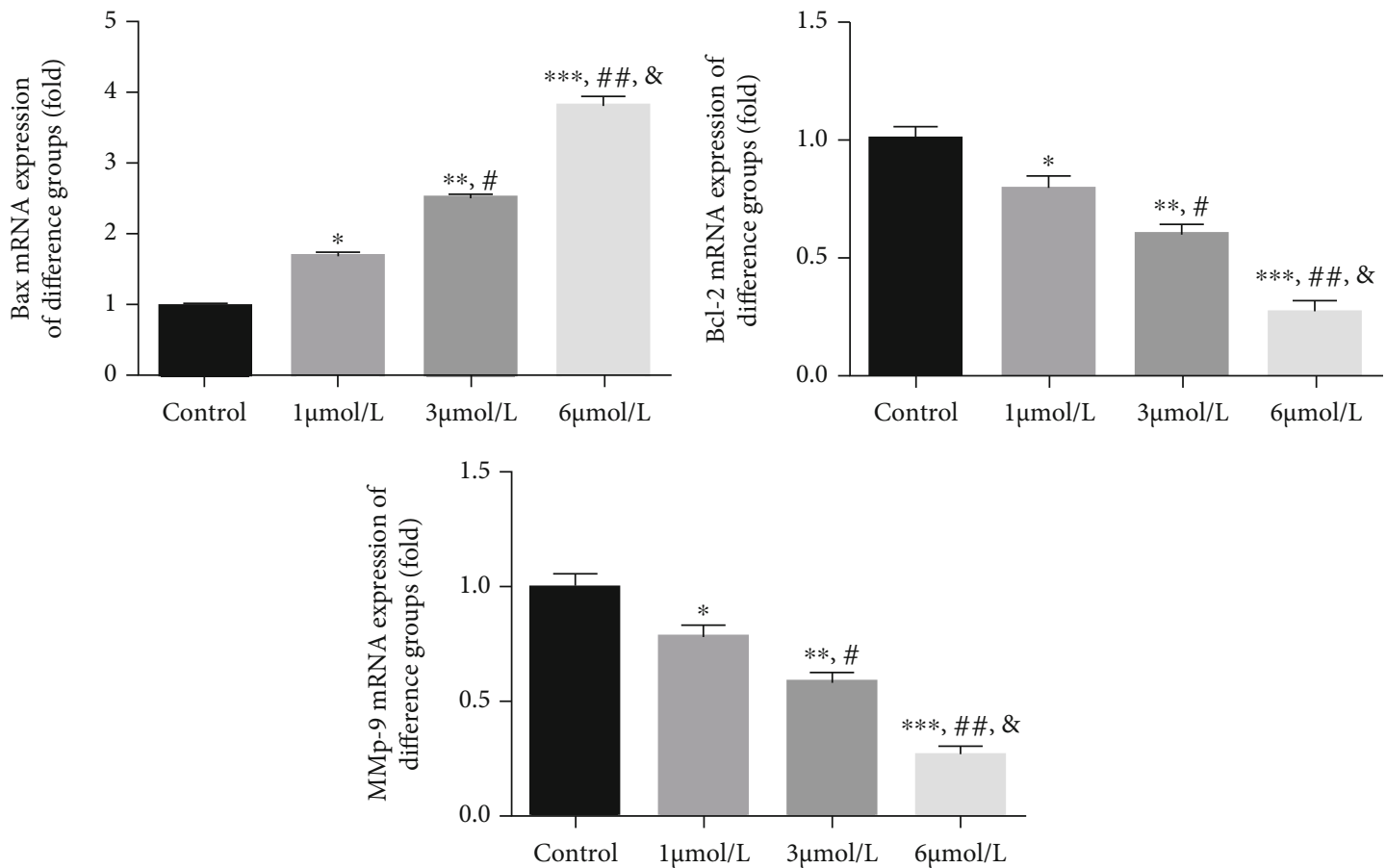

Figure 5: Relative mRNA expression by RT-PCR. ${ }^{*} P<0.05,{ }^{* *} P<0.01,{ }^{* * *} P<0.001$, compared with the control group; ${ }^{\#} P<0.05,{ }^{\# \#} P<0.01$, compared with $1 \mu \mathrm{mol} / \mathrm{L}$ group; ${ }^{\circledR} P<0.05$, compared with $6 \mu \mathrm{mol} / \mathrm{L}$ group.
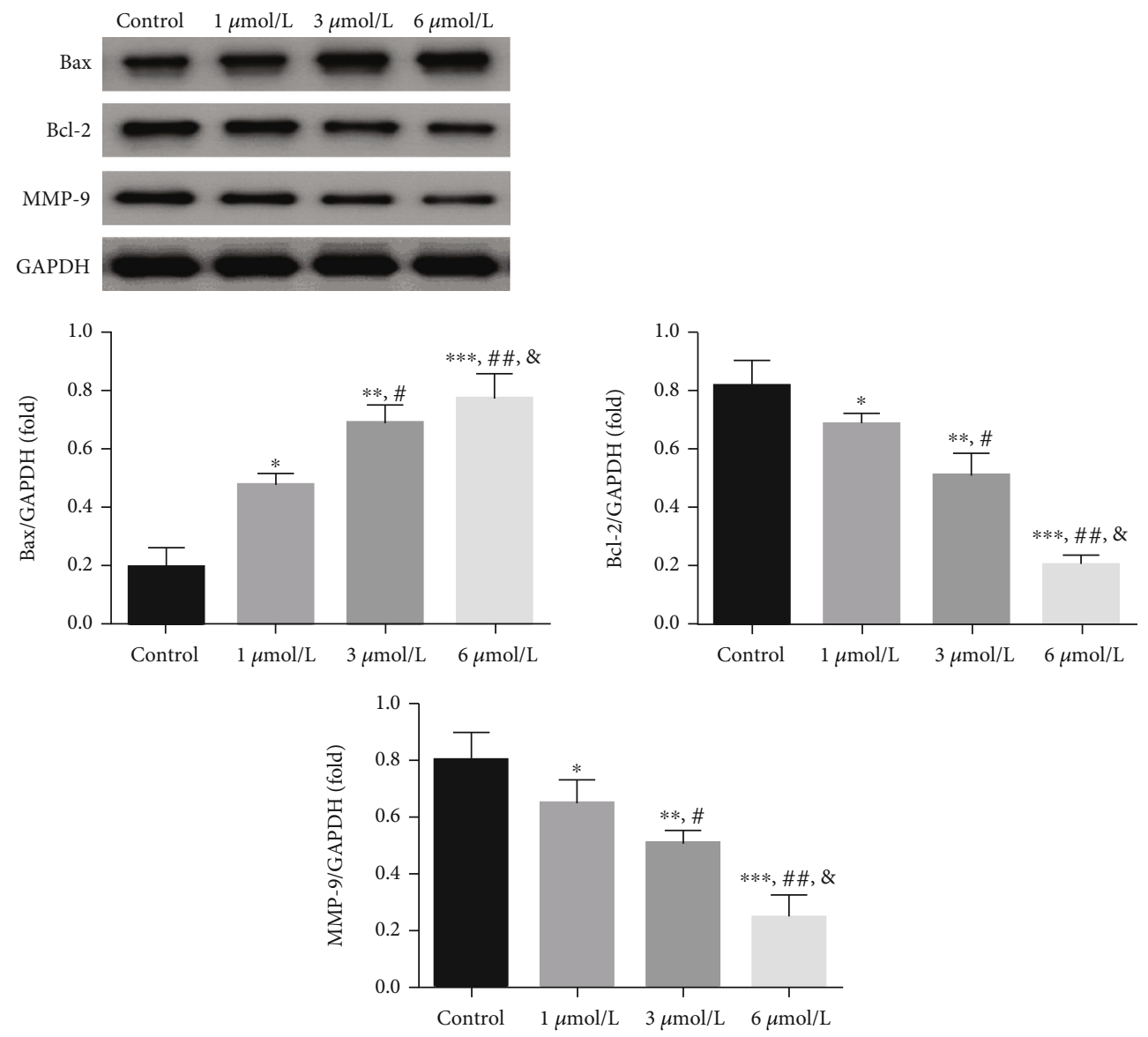

Figure 6: Relative protein expression by WB assay. ${ }^{*} P<0.05,{ }^{* *} P<0.01,{ }^{* * *} P<0.001$, compared with the control group; ${ }^{*} P<0.05$, ${ }^{\# \#} P<0.01$, compared with $1 \mu \mathrm{mol} / \mathrm{L}$ group; ${ }^{\circledR} P<0.05$, compared with $3 \mu \mathrm{mol} / \mathrm{L}$ group. 
the same as that of NP on the 4th day with the cumulative drug release rate of $72.37 \%$. This may be related to the physical and chemical properties of nanoparticles. When the material is processed to the nanoscale, due to the quantum size effect, the little size effect, and the surface effect, the nanoparticles will show the peculiar physical, chemical, and biological properties, which make the nanoparticles have some new characteristics and functions $[15,16]$. To further investigate the mechanism of NP for inhibiting the proliferation and migration of HUVSMCs, the related proteins were detected.

$\mathrm{Bcl}-2$ gene family is the most important related gene. Bcl2 gene can resist apoptosis induced by chemotherapeutic drugs. Bax is a homologous protein of Bcl-2, and it can not only produce homopolymer but also produce heterodimer with Bcl-2, thus eliminating the antiapoptosis effect of Bcl-2 gene; in this respect, it can promote apoptosis; on the other hand, it may also weaken the upregulation of telomerase activity by Bcl-2 [17-19]. In this study, the results showed Bcl-2 and Bax expressions in HUVSMCs changed significantly after NP intervention, showing a significant concentration-effect relationship. It is inferred that the apoptosis induced by NP may be closely related to Bcl-2 and Bax.

Matrix metalloprotease (MMPs) mediates basement membrane and extracellular matrix degradation and cell migration $[20,21]$. Moreover, MMP-9 is an important member of MMPs and is a key part in the degradation of collagen VI and other matrix proteins in basement membrane [22]. The results in this study showed MMP-9 gene and protein were significantly inhibited after NP intervention, which might be related to the inhibition effect of NP on HUSAMCs migration.

\section{Conclusions}

In conclusion, NP is an ideal slow release preparation, which can prolong the effective acting time of $\mathrm{As}_{2} \mathrm{O}_{3}$ on vascular smooth muscle cells and inhibit cell growth and induce apoptosis in vitro. It is also discussed that the molecular mechanism of NP inhibiting the proliferation and migration of HUVSMCs may be realized by regulating the expressions of Bcl-2, Bax, and MMP-9. This new dosage form is expected to become a drug coating on the surface of drug eluting stents in the future, which provides new idea and method for clinical prevention and treatment of restenosis in stents.

\section{Data Availability}

The figure and table data used to support the findings of this study are included within the article.

\section{Conflicts of Interest}

The authors declare no conflict of interest.

\section{Acknowledgments}

This research has been supported by the General medical research project of Jiangsu Health Commission (M2020062) and Hospital-level project of Jiangsu Province Hospital of Chinese Medicine (Y17010).

\section{References}

[1] R. Hoffmann and G. S. Mintz, "Coronary in-stent restenosis-predictors, treatment and prevention," European Heart Journal, vol. 21, no. 21, pp. 1739-1749, 2000.

[2] M. S. Lee and G. Banka, "In-stent Restenosis," Interventional Cardiology Clinic, vol. 5, no. 2, pp. 211-220, 2016.

[3] D. G. Kokkinidis, S. W. Waldo, and E. J. Armstrong, "Treatment of coronary artery in-stent restenosis," Expert Review of Cardiovascular Therapy, vol. 15, no. 3, pp. 191-202, 2017.

[4] J. Ni, G. Chen, Z. Shen et al., "Pharmacokinetics of intravenous arsenic trioxide in the treatment of acute promyelocytic leukemia," Chinese Medical Journal, vol. 111, no. 12, pp. 1107-1110, 1998.

[5] Y.-H. Kang, M.-J. Yi, M.-J. Kim et al., "Caspase-Independent cell death by arsenic trioxide in human cervical cancer Cells," Cancer research, vol. 64, no. 24, pp. 8960-8967, 2004.

[6] M. Hoonjan, V. Jadhav, and P. Bhatt, "Arsenic trioxide: insights into its evolution to an anticancer agent," Journal of Biological Inorganic Chemistry, vol. 23, no. 3, pp. 313-329, 2018.

[7] Z. Diaz, M. Colombo, K. K. Mann et al., “Trolox selectively enhances arsenic-mediated oxidative stress and apoptosis in APL and other malignant cell lines," Blood, vol. 105, no. 3, pp. 1237-1245, 2005.

[8] Z. Yang, M. Yang, and J. Peng, "Evaluation of arsenic trioxideloaded albumin nanoparticles as carriers: preparation and antitumor efficacy," Drug development and industrial pharmacy, vol. 34, no. 8, pp. 834-839, 2008.

[9] K. Ward, J. G. C. Cortés, and D. Stuckey, "Alginate as a support ligand for enhanced colloidal liquid aphron immobilization of proteins and drug delivery," Biotechnology and Bioengineering, vol. 116, no. 12, pp. 3168-3178, 2019.

[10] D. N. Kapoor, A. Bhatia, R. Kaur, R. Sharma, G. Kaur, and S. Dhawan, "PLGA: a unique polymer for drug delivery," Therapeutic delivery, vol. 6, no. 1, pp. 41-58, 2015.

[11] G. Amasya, U. Badilli, B. Aksu, and N. Tarimci, "Quality by design case study 1 : design of 5-fluorouracil loaded lipid nanoparticles by the W/O/W double emulsion solvent evaporation method," European Journal of Pharmaceutical Sciences, vol. 10, pp. 92-102, 2016.

[12] T. K. Giri, C. Choudhary, A. Alexander, H. Badwaik, and D. K. Tripathi, "Prospects of pharmaceuticals and biopharmaceuticals loaded microparticles prepared by double emulsion technique for controlled delivery," Saudi Pharmaceutical Journal, vol. 21, no. 2, pp. 125-141, 2013.

[13] T. Mosmann, "Rapid colorimetric assay for cellular growth and survival: application to proliferation and cytotoxicity assays," Journal of lmmunological Methods, vol. 65, no. 1-2, pp. 55-63, 1983.

[14] M. F. Brancati, F. Burzotta, C. Trani, O. Leonzi, C. Cuccia, and F. Crea, "Coronary stents and vascular response to implantation: literature review," Pragmatic and observational research, vol. 13, no. 8, pp. 137-148, 2017.

[15] H. Chen, X. Zheng, Y. Chen, M. Li, K. Liu, and X. Li, "Influence of copper nanoparticles on the physical-chemical properties of activated sludge," PLoS One, vol. 9, no. 3, 2014.

[16] J. Zhang, H. Tang, Z. Liu, and B. Chen, "Effects of major parameters of nanoparticles on their physical and chemical properties and recent application of nanodrug delivery system in targeted chemotherapy," International Journal of Nanomedicine, vol. Volume 12, pp. 8483-8493, 2017. 
[17] C. J. Larsen, "The BCL2 gene, prototype of a gene family that controls programmed cell death (apoptosis)," Annals Genetic, vol. 37, no. 3, pp. 121-134, 1994.

[18] Y. Zhang, X. Yang, X. Ge, and F. Zhang, "Puerarin attenuates neurological deficits via Bcl-2/Bax/cleaved caspase-3 and Sirt3/SOD2 apoptotic pathways in subarachnoid hemorrhage mice," Biomed Pharmacother, vol. 109, pp. 726-733, 2019.

[19] C. Yao, X. Cao, Z. Fu et al., "Boschniakia rossica polysaccharide triggers laryngeal carcinoma cell apoptosis by regulating expression of Bcl-2, Caspase-3, and P53," Medical science monitor, vol. 29, no. 23, pp. 2059-2064, 2017.

[20] H. Huang, "Matrix metalloproteinase-9 (MMP-9) as a cancer biomarker and MMP-9 biosensors: recent advances," Sensors, vol. 18, no. 10, p. 3249, 2018.

[21] A. Hrabia, D. Wolak, and M. Kwaśniewska, "Expression of gelatinases (MMP-2 and MMP-9) and tissue inhibitors of metalloproteinases (TIMP-2 and TIMP-3) in the chicken ovary in relation to follicle development and atresia," Theriogenology, vol. 125, pp. 268-276, 2019.

[22] P. Wang, L. D. Zhang, M. C. Sun, W. D. Gu, and H. Z. Geng, "Over-expression of mir-124 inhibits MMP-9 expression and decreases invasion of renal cell carcinoma cells," European review for medical and pharmacological sciences, vol. 22, no. 19, pp. 6308-6314, 2018. 